\title{
The Biopolitics of Stalinism : Ideology and Life in Soviet Socialism
}

\section{Tynkkynen, Veli-Pekka}

\section{7}

Tynkkynen, V-P 2017 , ' The Biopolitics of Stalinism : Ideology and Life in Soviet Socialism ' , Slavic Review , vol. 76 , no. 3 , pp. 846-847 . https://doi.org/10.1017/slr.2017.229

http://hdl.handle.net/10138/231876

https://doi.org/10.1017/slr.2017.229

cc_by

acceptedVersion

Downloaded from Helda, University of Helsinki institutional repository.

This is an electronic reprint of the original article.

This reprint may differ from the original in pagination and typographic detail.

Please cite the original version. 
The Biopolitics of Stalinism. Ideology and Life in Soviet Socialism. By Sergei Prozorov. Edinburgh: Edinburgh University Press, 2016. xiii, 337 pp. Notes. Bibliography. Index. Paper.

“Did you know, Stalin was a hipster?" is printed on a T-shirt, together with a picture of young Iosif Dzhugashvili, sold at a tourist shop in Moscow. It is very puzzling to see the communist leader responsible for millions of deaths glorified in contemporary Russia that is characterized by nonideological political nihilism accompanied by "mindless consumerism and superstitious religiosity" (p. 259), as described by the author Sergey Prozorov. His book is extremely interesting for those trying to understand the nature of Stalin's terror, and the whole Soviet socialist enterprise, as well as the roots of rationalities of today's ideology-poor, but imperialist-minded Russia. Typically, the Stalin era has been approached with concepts like totalitarianism, when many scholars find little differences between Nazism and Communism. Or then it is looked from ideological and governance angles, stating in the former case that Stalin's terror is a proof that socialism always leads to atrocities or as in the latter debate claiming that the implementation just has been flawed, thus the ideology should not be blamed. According to Prozorov, this has distorted the whole analysis of Russian political history. 
Prozorov, expert on Russian politics and history, proposes a different and, in my view, very solid, methodological tool to reveal the essence of the Soviet socialist enterprise and Stalin's rule. By operationalizing the concept of biopolitics, and leaning on the works of Michel Foucault, Giorgio Agamben and Roberto Esposito, Prozorov manages to unfold the specificities of Stalin's power. The main argument concerning the interpretation of Stalin's rule is that it was qualitatively very different what we have come to think of biopolitics. In the mainstream understanding of biopolitics, by which both liberal democracies and totalitarian Nazism have been analyzed, the core value of the rule has been to protect life: even the genocide of Jews by the Nazis was carried out to protect the alleged Aryan blood and form of life attached to it. Therefore, in Western examples of biopolitics the societal danger has been linked to the excess of protection of life. Stalin's biopolitics turned into thanatopolitics (politics of death), i.e. into a total eradication of previous forms of life - a war on nature, human and physical. 
Prozorov shows with his theoretical elaborations on the interplay of ideology and form of life, and empirical analysis of the Soviet and post-Soviet era that Stalin's rule and its rehabilitation in contemporary Russia can be understood with the help of biopolitical analysis. Prozorov leans on secondary research material, thus the book does not contain any new archival data and thus may not interest hard core historians. However, exactly because of this the book is brilliant: it is the approach, the methodology that is able to unveil how in Russia the relationship between the rulers and the people, and especially rulers' views about preferred and allowed forms of lives, has evolved during the course of history. More, all the efforts to de-Stalinize the Russian society, both during the Soviet and post-Soviet eras, were not successful precisely because the focus has been on ideology and implementation, not the stance political power has had vis-à-vis the people and their forms of life. Thus, the book demonstrates the logical path why in the 2010's many Russians continue to see Stalin as a patriotic and positive figure, and how Putin can be represented as Stalin's heir as an 'effective manager'. However, valorization of Stalinism is not risk free for Putin's reign, as Putinism is not about transformation, as in Stalinism, but preservation.

The book is not just about unveiling harmful practices, as many Foucauldian studies have been accused of, but proposes new approaches how to empower people. Prozorov proposes to battle the ideology-poor Russian society, since “(a) pure biopolitics 'without ideas' is in fact a particularly powerful ideological construct." (p. 256), with a tool he calls affirmative biopolitics. Hence, the idea (e.g. equity, sustainability) should not be imposed on people, as in Stalinism, but it should be diffused, as was the case with socialism in the early 1920's Soviet Russia, with the help of affirmative biopolitics. More, the biopolitical-emancipatory take can reveal, for example, how fragile the truth claims of neo-Stalinism under Putin's rule are. Thus, one should not be discouraged by the fact that in today's Russia it is exceptionally hard to influence politics and policies via rational arguments, as naked power prevails over rationality. However, the dangers of genuine reStalinization might be the key to a positive transformation along the lines of affirmative biopolitics. 
Veli-Pekka Tynkkynen

Aleksanteri Institute, University of Helsinki 